研

究

\title{
低Mo 系プレアロイ鋼粉一焼結浸炭熱処理材の特性に及ぼすCu添加の影響
}

\author{
宇波繁，尾㟝由紀子
}

JFE スチール(侏スチール研究所, = 260-0835千葉市中央区川崎町 1 .

\section{Effect of Copper Addition on Mechanical Properties of Sintered and Case-hardened Compacts Made of Low Molybdenum Prealloyed Steel Powder}

\author{
Shigeru Unami and Yukiko Ozaki \\ JFE Steel Corporation, Steel Research Laboratory, 1 Kawasaki-cho, Chuo-ku, Chiba 260-0835, Japan.
}

Received March 2, 2009

SYNOPSIS

The effect of copper powder addition on properties of sintered and case-hardened compacts made of the 0.45 mass $\%$ Mo prealloyed steel powder has been investigated. The tensile strength of sintered and case-hardened compacts made of the powder increased with 1 mass $\% \mathrm{Cu}$ addition, but leveled off with 2 mass $\% \mathrm{Cu}$ addition. The rotating bending fatigue strength of sintered and case-hardened compacts made of the powder increased with 1 mass $\% \mathrm{Cu}$ addition. However, the fatigue strength decreased with 2 mass $\% \mathrm{Cu}$ addition and was lower than that of $\mathrm{Cu}$ free material. The tensile and fatigue strengths of sintered and case-hardened compacts made of the powder with 1 mass $\% \mathrm{Cu}$ addition are equal to those made of the conventional 4 mass $\% \mathrm{Ni}$ diffusion-alloyed steel powder. The reduction of fatigue strength with 2 mass $\% \mathrm{Cu}$ addition should be attributed to an increase in size of the maximum pore due to $\mathrm{Cu}$ liquid phase and probably an increase in fatigue crack growth rate due to $\mathrm{Cu}$ addition. KEY WORDS

molybdenum, copper, tensile strength, fatigue strength, carburizing

\section{1 緒言}

鉄系焼結部品は, 最終製品形状に近い部品が安価に大量生 産できるという特徵があるため, 自動車部品に広く用いられ ている. 自動車の燃費向上に伴い，鉄系焼結部品も高強度化 による小型・軽量化が指向されている.

鉄系焼結部品を高強度化するためには, 合金成分を添加す る方法が一般的である. 合金鋼粉の中でも, 微細な Ni粉を鉄 粉粒子表面に拡散付着させた Ni系拡散合金鋼粉"'が焼結後の 強度が高いため, 高強度焼結部品に広く用いられている. ま た,さらに高強度化するために, 焼結後に浸炭熱処理などの 後処理を施すことも多い.ただし，近年の合金成分の原料価 格の高騰により，鉄系焼結部品の製造コストの上昇が問題と なっていた。

著者らは, 従来 $\mathrm{Ni}$ 系拡散合金鋼粉之同等程度の焼結後の強 度が得られる低Mo 系プレアロイ鋼粉 $(0.45$ mass $\%$ Mo $)$ をべー スにCu粉を添加した偏析防止処理粉を開発し,その特性につ いて報告した ${ }^{2)}$.
鉄系焼結材料用の原料粉に添加する合金元素としては, Mo は, 酸素との親和力が低く, 焼結温度でも容易に還元可能で あること, 焼入れ性倍数が大きいことの利点により重要な元 素であり, 従来から多くの報告3-5)がある. 例えば, バルブシー 卜用原料粉の $\mathrm{Fe}-5$ mass\%Moプレアロイ粉 ${ }^{33}$, $\mathrm{Fe}-1.5$ mass\% Mo プレアロイ粉4), Fe-0.85 mass\% Mo プレアロイ粉(5)などの報告 がある.

そこで, 焼結後に浸炭熱処理を行う材料についても, 従来 $\mathrm{Ni}$ 系拡散合金鋼粉と同等程度の特性を実現することを目的と して, 低Mo系プレアロイ鋼粉をベースとして, $\mathrm{Cu}$ 粉を添加 した偏析防止処理粉により，最適な配合を検討した。

低Mo系プレアロイ鋼粉にCu粉を添加した系の焼結体特性 についてはいくつか報告6.7)があるが, 浸炭熱処理材の特性へ の $\mathrm{Cu}$ の影響については詳細な報告が少ない.

本報告では, 低 Mo 系プレアロイ鋼粉にCu粉, 黒鉆粉を添 加した焼結浸炭熱処理材の機械的特性に及ぼす $\mathrm{Cu}$ 添加の影 響について報告する. 


\section{2 試料および実験方法}

\section{1 原料粉}

$\mathrm{Fe}-0.45 \mathrm{mass} \% \mathrm{Mo}$ プレアロイ鋼粉 (JFE スチール侏)製，JIP $4 \mathrm{MOA}$, 平均粒径 $80 \mu \mathrm{m}$ )に, アトマイズ $\mathrm{Cu}$ 粉 (平均粒径 $35 \mu \mathrm{m}$ ) $0 \sim 2$ mass\%, 天然黒鉛粉 (平均粒径 $5 \mu \mathrm{m}$ ) $0.3,0.5$ mass $\%$, 高 密度成形用潤滑剂 ${ }^{8)} 0.5$ mass\%を添加し, 偏析防止処理を行っ た粉末，および $\mathrm{Fe}-4$ mass\% $\mathrm{Ni}-1.5$ mass\% $\mathrm{Cu}-0.5$ mass\% Mo 拡散合金鎙粉 (JFE スチール(侏)製，JIPシグマロイ $415 \mathrm{~S}^{1)}$ ，平 均粒径 $80 \mu \mathrm{m}$, 以下, $4 \mathrm{Ni}$ 系合金鋼粉と記す)に天然黒鉛粉 0.3 mass\%, ステアリン酸亜鉛粉0.8 mass\%を混合した粉末を供試 粉とした.

\section{2 試験片作製条件}

これらの供試粉を成形圧力 $590 \mathrm{MPa}$ で成形した後, $1130^{\circ} \mathrm{C}$, 20 分, 吸熱型プロパン变成ガスで焼結した. その後, 浸炭熱 処理 (浸炭: $900^{\circ} \mathrm{C}, 60$ 分, カーボンポテンシャル $0.8 \%$, 焼 入れ: $60^{\circ} \mathrm{C}$ 油中，焼き戻し: $180^{\circ} \mathrm{C}, 60$ 分)を行った。

2.3 評価方法

圧粉体および焼結体の密度はJIS Z 2501 に基づいて測定し た. 引張試験は, 平行部径 $5 \mathrm{~mm}$, 長さ $15 \mathrm{~mm}$ の小型丸棒試 験片を焼結後に機械加工により作製し, 浸炭熱処理後にJIS Z 2241 に基づき評価した。シャルピー衝撃值は，JIS Z 2550 に 準拠したノッチなしの長さ $55 \mathrm{~mm}$ ，幅 $10 \mathrm{~mm}$ ，高さ $10 \mathrm{~mm}$ の 試験片を用いて測定した。ロックウェル硬度, ビッカース硬 度を, JIS Z 2245, 2244に従い測定した. 回転曲げ疲労試験は, 平行部径 $8 \mathrm{~mm}$, 長さ $15.4 \mathrm{~mm}$ の平滑丸棒試験片を焼結後に機 械加工により作製し，浸炭熱処理後に小野式回転曲げ疲労試 験機により回転数 $3000 \mathrm{rpm}$, 応力比 $\mathrm{R}=-1$ の条件で実施した. 耐久限度以繰り返し数 $10^{7}$ 回において破壊しない応力として 求めた。組織観察は, 焼結浸炭熱処理材の切断研磨面を 3 mass\% 硝酸アルコール溶液で腐食した後, 光学顕微鏡を用い て行った. 浸炭熱処理後の $\mathrm{C}$ 量分布は, 焼結浸炭熱処理材切 断研磨面について, 電子プローブX 線マイクロアナリシス (EPMA)によるスポット定量分析により測定した. また, 残留 オ一ステナイト量は，焼結浸炭熱処理材表面について，Mo$\mathrm{K} \alpha$ 線を用いた X 線回折を行い, $\alpha-\mathrm{Fe}$ の (110), (200) および (211) 面, $\gamma$ - $\mathrm{Fe}$ の (111), (200), (220) および(311) 面の積分強度 を測定し，直接比較法により算出した.

\section{3 実験結果}

圧粉密度, 焼結密度および焼結寸法変化率(成形体基準)を Fig.1 に示す．圧粉密度は，Cu粉の添加量が多くなるほど高 くなり, 黒鉛粉の添加量が多くなるほど低くなる.これは, $\mathrm{Cu}$ の比重が 8.95 と鉄 $(7.87)$ より重く，黒鉛の比重が 2.25 と鉄よ り軽いためと考えられる.また， Cu粉の添加量が多くなるほ ど, 焼結寸法変化率が膨張傾向となり, 焼結密度は低くなる. これは，焼結時に， Cu粉が融解し， $\mathrm{Cu}$ 液相が粒界および旧 粉末粒界に侵入し膨張する, いわゆる $\mathrm{Cu}$ 膨張現象 ${ }^{9}$ に起因す る. 黒鉛量 $0.3,0.5$ mass\% で比較すると, 黒鉛粉の添加量が多 いほうが焼結時の膨張量が小さい。これは， $\mathrm{Fe}-\mathrm{Cu}-\mathrm{C}$ 系にお
いて，Fe中にCが固溶することによって結晶粒境界および結 晶粒内への $\mathrm{Cu}$ の拡散速度の減少により $\mathrm{Cu}$ 膨張が抑制 ${ }^{9}$ され ていることと同様の現象と考えられる.

$\mathrm{Cu}$ 添加量と焼結浸炭熱処理材の引張強さ, 衝撃值および硬 さの関係をFig.2に示す.引張強さについては, いずれの黒鉛 添加量でも， 1 mass\%の Cu添加により，Cu無添加材より 100 MPa 程度高くなる. 2 mass\%の Cu 添加では, 1 mass\% $\mathrm{Cu}$ 添加 材とほぼ同等の值である. 黒鉛添加量による差はほとんどな い. $1 \sim 2$ mass\% の Cu 添加により従来 $4 \mathrm{Ni}$ 系合金材と同等の 引張強さが得られる。

衝撃值については, いずれの黒鉛添加量でも, $\mathrm{Cu}$ 添加量が 増えるに従い，わずかに高くなる $(2$ mass\% $\mathrm{Cu}$ 添加で 2 ～ $3 \mathrm{~J} /$ $\mathrm{cm}^{2}$ ). 黒鉛添加量が少ないほうがわずかに衝撃値が高い. 硬 さは，いずれの黒鉛添加量でも，Cu添加量が増えるに従い低 くなる．黒鉛添加量による差はほとんどない，従来 $4 \mathrm{Ni}$ 系合 金材と比べると, いずれの Cu添加量でも, 衝撃值が低く, 硬 さが高い.

$\mathrm{Cu}$ 添加量と焼結浸炭熱処理材の回転曲げ疲れ強さの関係を Fig.3に示す. 回転曲げ疲れ強さは, 1 mass\% Cu添加により $\mathrm{Cu}$ 無添加材より高くなる。0.5 mass\% 黒鈶添加のほうが, 0.3
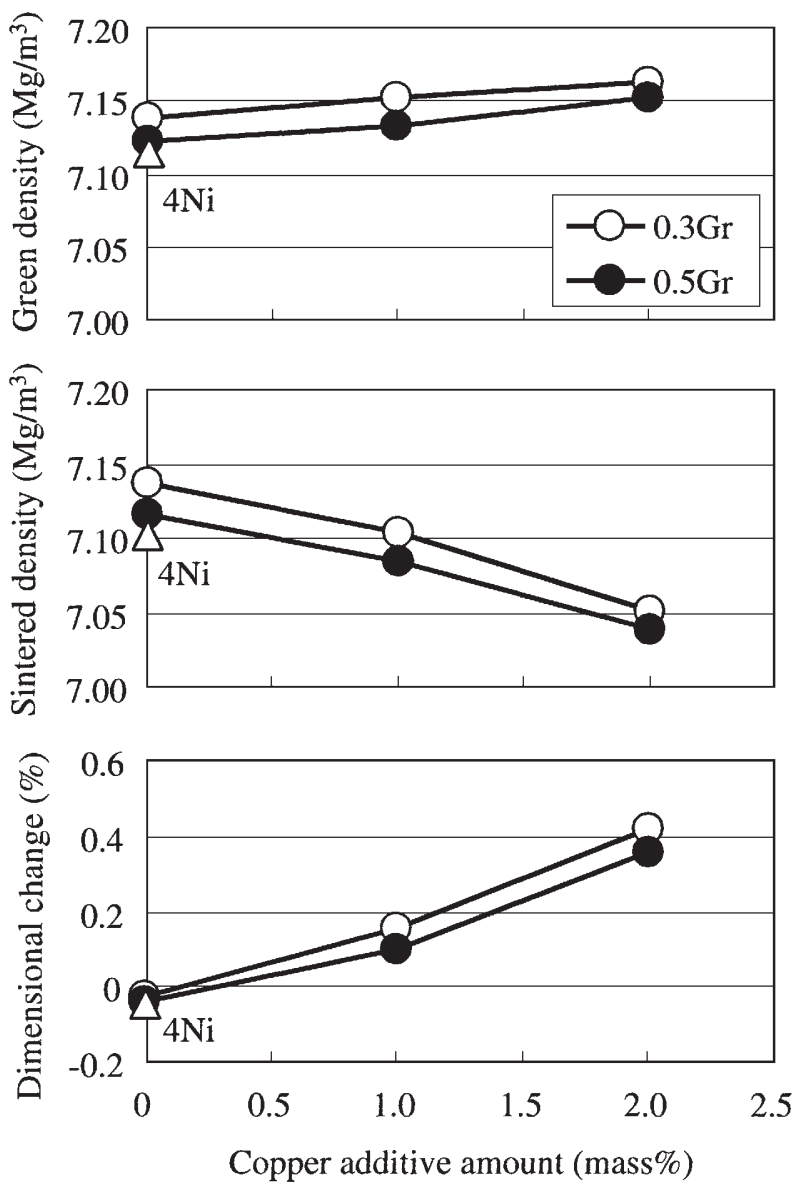

Fig.1 Effects of copper addition on densities of green and sintered compacts and dimensional changes during sintering of the low molybdenum prealloyed steel powder. 

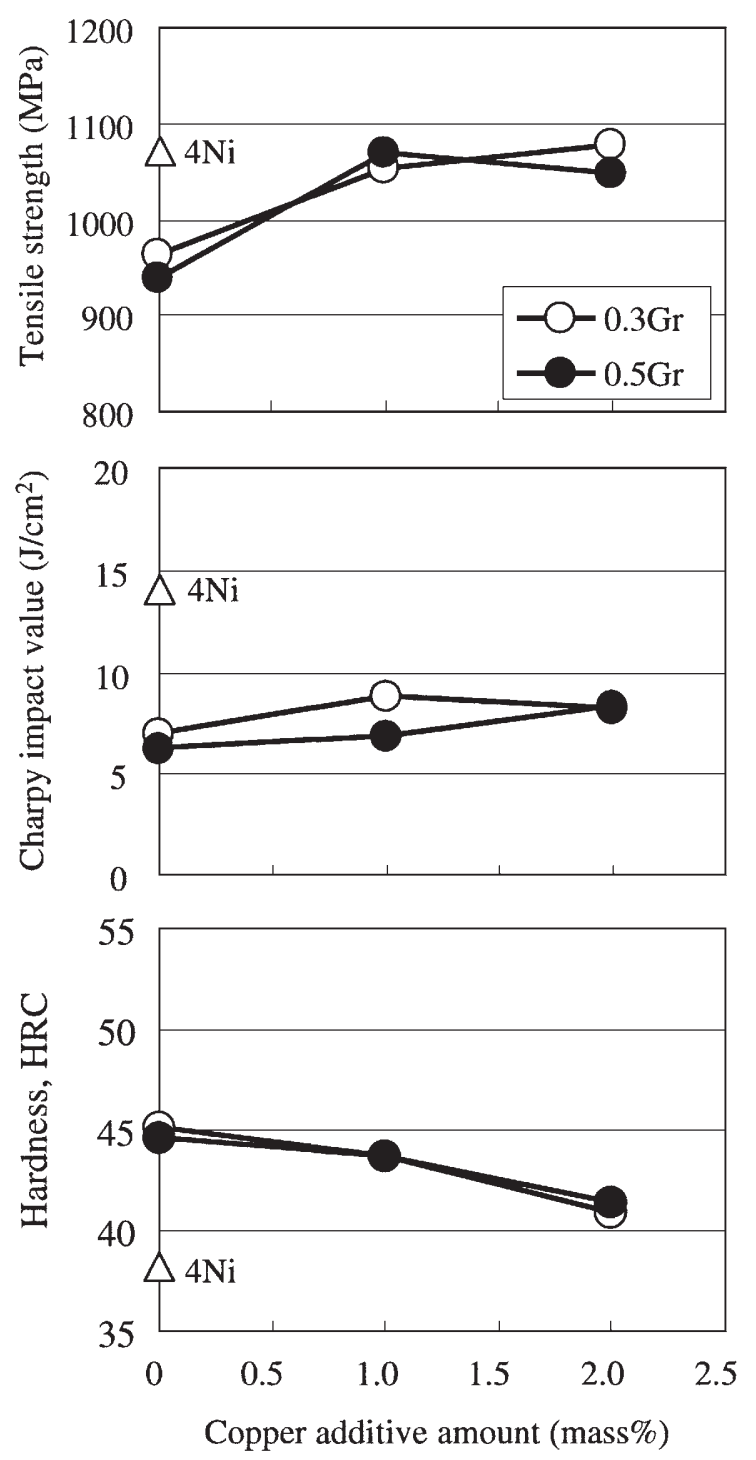

Fig.2 Effects of copper addition on tensile strength, Charpy impact value and hardness of the sintered and case-hardened compacts made of the low molybdenum prealloyed steel powder.

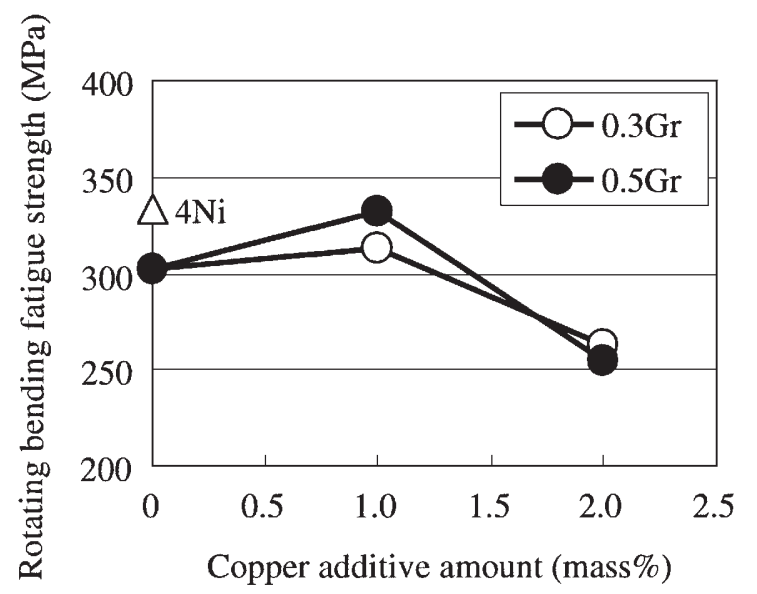

Fig.3 Effect of copper addition on rotating bending fatigue strength of the sintered and case-hardened compacts made of the low molybdenum prealloyed steel powder. (a) $0 \mathrm{Cu}-0.5 \mathrm{Gr}$

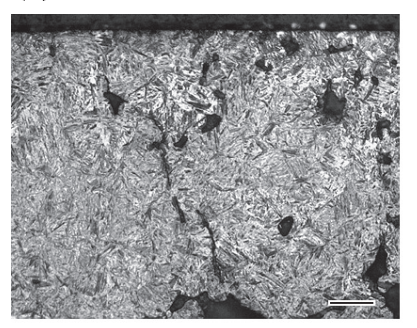

(c) $2 \mathrm{Cu}-0.5 \mathrm{Gr}$

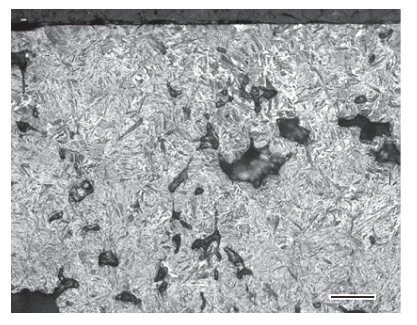

(b) $1 \mathrm{Cu}-0.5 \mathrm{Gr}$

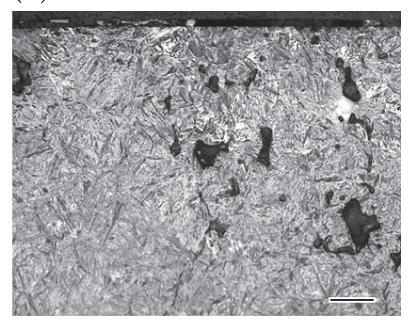

(d) $4 \mathrm{Ni}$

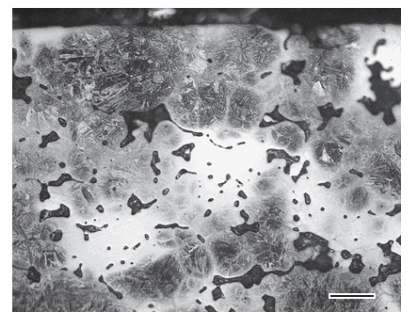

$25 \mu \mathrm{m}$
Fig.4 Cross-sectional microstructures of the sintered and casehardened compacts made of the low molybdenum prealloyed steel powder with copper addition ( 0.5 mass\% graphite addition).

mass\% 黒鉛添加に比べわずかに高く, $330 \mathrm{MPa}$ の回転曲げ疲 れ強さが得られる.ただし,いずれの黒鉛添加量でも, 2 mass\% Cu添加では, 1 mass\% Cu 添加よりも低下する. 0.5 mass\% 黒 鈶添加, 1 mass\% $\mathrm{Cu}$ 添加により, 従来 $4 \mathrm{Ni}$ 系合金材と同等の 值が得られる.

0.5 mass\%黒鈶添加した焼結浸炭熱処理材の表面部の断面組 織を Fig.4 に示す. 均一な焼き戻しマルテンサイト組織を示 し, $\mathrm{Cu}$ 添加量が増えても, ほとんど差が認められない. 0.3 mass\% 黑鉛添加材もほとんど変わらない, 一方, 従来 $4 \mathrm{Ni}$ 系 合金材は, $\mathrm{Ni}$ の濃化部 ${ }^{1)}$ である白色の組織が認められる. Fig.2 に示した低衝撃値, 高硬さの原因は, 従来4 $\mathrm{Ni}$ 系合金材では, 焼結時の Ni の拡散が不十分なため, 軟らかい Ni の濃化部が 焼結体中に残留しているが, $\mathrm{Mo}-\mathrm{Cu}$ 系では, $\mathrm{Cu}$ は液相を生 成して焼結体中に広がりやすく, 低硬度の濃化部が残りにく いためと考えられる.

\section{4 考察}

低 Mo 系プレアロイ鋼粉 $(0.45 \mathrm{mass} \% \mathrm{Mo})$ への Cu粉添加量 が, 1 mass\%から 2 mass\%に増えると, 焼結浸炭熱処理材の 引張強さが横ばいであるのに対し, 回転曲げ疲れ強さは低下 し, $\mathrm{Cu}$ 無添加材よりも低くなったことを示した. 引張強さと 疲れ強さに及ぼす $\mathrm{Cu}$ の影響の違いについて考察する.

$\mathrm{Cu}$ は, 焼結時に液相を生成することにより, 焼結を促進す る効果があり, 粒子の結合を強化する機能がある.その他, 焼 結浸炭熱処理材の特性に影響を及ぼす要因としては, 硬さ分 布, 気孔分布, 残留オーステナイト量, 疲労き裂進展挙動が 挙げられ,これらの要因に, Cuがどのように影響しているか 調べた. 
焼結浸炭熱処理材の硬さ分布をFig.5に示す. 黒鉛添加量が 多いほうが表面および内部の硬さは高いが, $\mathrm{Cu}$ 添加量が変 わっても, 大きな差は認められない. 焼結浸炭熱処理材のC
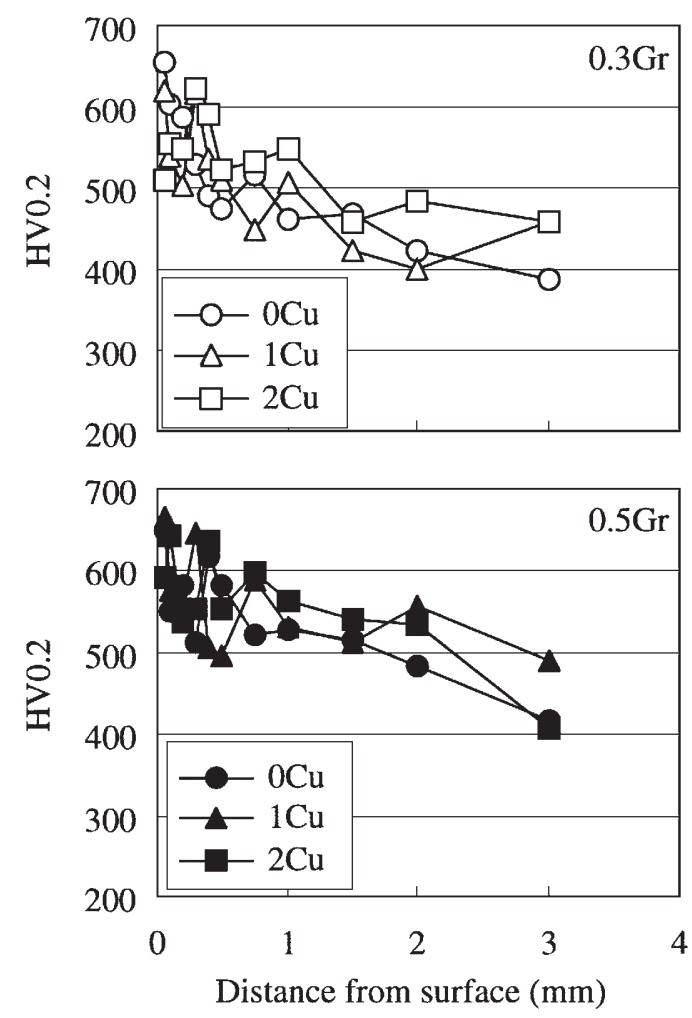

Fig.5 Microhardness profiles of the sintered and case-hardened compacts made of the low molybdenum prealloyed steel powder with copper addition.
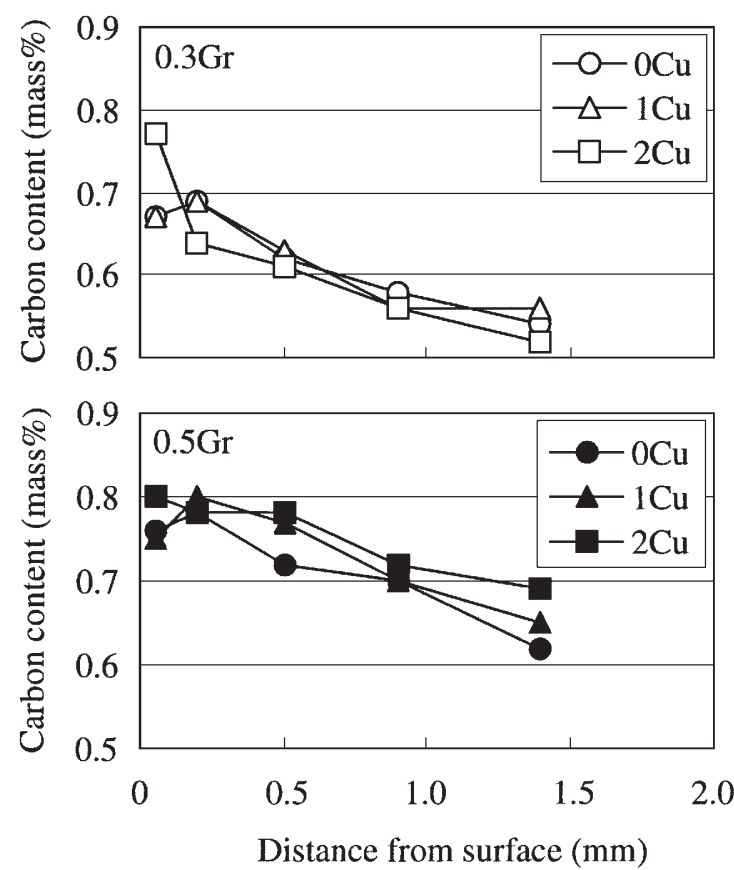

Fig.6 Carbon content profiles of the sintered and case-hardened compacts made of the low molybdenum prealloyed steel powder with copper addition.
量分布をFig.6に示す. 黒鈶添加量が多いほうが表面部( 1.5 $\mathrm{mm})$ の $\mathrm{C}$ 量は高いが, $\mathrm{Cu}$ 添加量が変わっても, 大きな差は認 められない.したがって, 今回の浸炭熱処理条件では, $\mathrm{Cu}$ は, 浸炭挙動および焼入れ性に大きな影響汲及ぼしていないと考 えられる。

焼結浸炭熱処理材の気孔径分布を, 切断研磨面の写真の画 像解析 (ImageJ 使用, 範囲 $0.96 \mathrm{~mm}^{2}$ ) により測定した結果を Fig.7に示す. 微細な気孔径分布にはほとんど差がなく, 粗大 な気孔径に差が認められる.そこで, Fig.7の結果から最大気 孔径を求め, $\mathrm{Cu}$ 添加量で整理した結果を Fig.8に示す. $\mathrm{Cu}$ 量 が増えるに従い, 最大気孔径が増加することが分かる。この 粗大な気孔は $\mathrm{Cu}$ 液相の流出により生成した気孔と考えられ る, 粗大な気孔は, 応力集中の原因となるため, 疲労き裂発 生の起点となる. また, 焼入れ材では, 焼結まま材に比べ, 応 力集中に対して敏感になっていると考えられ, 粗大な気孔へ の応力集中が高まると考えられる．これらの影響のため, 粗 大な気孔は引張強さより疲れ強さに対して強い影響を及ぼす と考えられる.

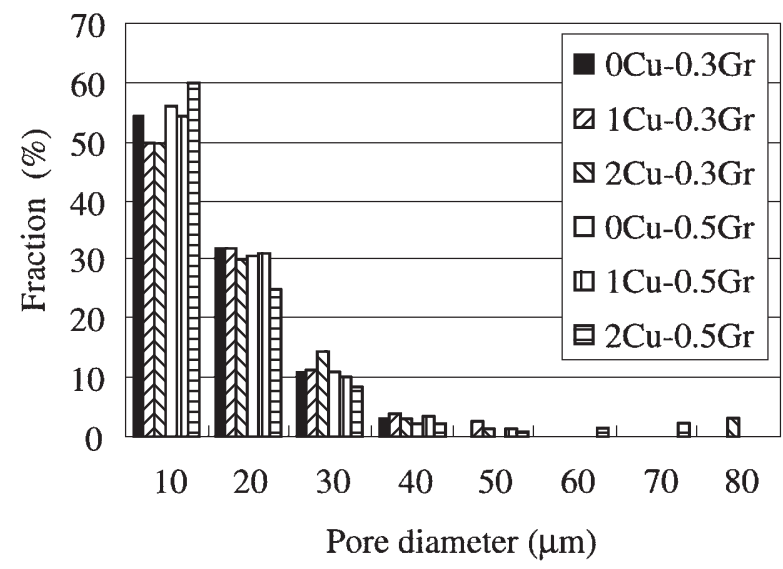

Fig.7 Pore size distributions of the sintered and case-hardened compacts made of the low molybdenum prealloyed steel powder with copper addition.

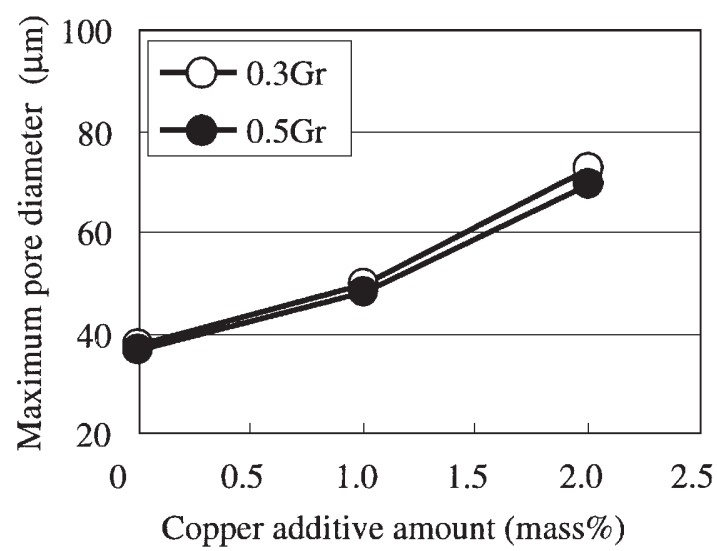

Fig.8 Maximum pore size of the sintered and case-hardened compacts made of the low molybdenum prealloyed steel powder with copper addition. 
焼結浸炭熱処理材の残留オーステナイト量をFig.9に示す. $\mathrm{Cu}$ は，Ms 点を低下させ，残留オーステナイト量を増大する 効果があることが知られている ${ }^{10)}$. ばらつきはあるが，Cuが 増えるに従い, 残留オーステナイト量は増加する傾向にある. 疲労強度への残留オーステナイトの影響については, 組成, 製造条件などによって異なるようであり，有益説 ${ }^{11,12)}$ と有害 説 ${ }^{13)}$ の両方の報告がなされている. 有益に働く機構として は, 残留オーステナイトの加工誘起変態による圧縮残留応力 の発生, あるいは残留オーステナイトが軟らかいため, 応力 集中を緩和するというものである.有害に働く機構としては, 残留オーステナイトは柔らかいため疲労破壊の起点となり， 疲労強度を低下させるというものである.今回の実験では, Cu添加量の増加に伴う残留オーステナイトの増加量はわずか であり, Fig.2に示したように, 衝撃值を向上させ, 硬さを低 下させる原因となり得ても, 急激に疲れ強さを低下させる原 因になるとは考えにくい.

0.3 mass\% 黒鈶添加した焼結浸炭熱処理材の疲労破面を Fig.10に示す. いずれの材料にも疲労き裂進展に伴うストラ イエーションが認められる. Saritasらにより, Fe-0.85mass\% Mo プレアロイ鋼粉に $2 \mathrm{mass} \% \mathrm{Cu}$ を添加した焼結焼入れ材で は, Fe-0.85 mass\%Mo プレアロイ鋼粉単独の焼結焼入れ材に 比較してき裂進展速度が $12 \%$ 大きくなる ${ }^{6}$ と報告されてい る. ストライエーションの間隔は, き裂進展速度に対応する が, 今回の破面では, ストライエーションの間隔のばらつき が大きく, $\mathrm{Cu}$ 添加量による差は読み取れない.ただし, $\mathrm{Cu}$ 添 加量が 2 mass\%に增加したときに, 引張強さは低下せず, 疲 れ強さの低下が大きいことを考慮すると, き裂進展速度の影 響は小さくないと考えられる. 今後, さらに詳細に検討する 必要がある.

以上の結果から, 1 mass\%の Cu 添加では, $\mathrm{Cu}$ 液相生成に よる焼結促進効果が $\mathrm{Cu}$ 液相の流出孔に起因する最大気孔径 の増加に優り, 疲労強度は向上するが, 2 mass\%の Cu添加で は, 最大気孔径の增加に加え, $\mathrm{Cu}$ 添加によるき裂進展速度の 増加も疲労強度を低下させる原因として影響している可能性 が高いと考えられる。

\section{5 結 言}

低Mo系プレアロイ鋼粉 $(0.45$ mass\% Mo) の焼結浸炭熱処理 材の特性に及ぼす $\mathrm{Cu}$ 粉添加量の影響を調べた. 主要な結果を 以下に示す.

(1) 焼結浸炭熱処理材の引張強さは, $1 \mathrm{mass} \%$ の $\mathrm{Cu}$ 添加によ り高くなり， 2 mass\% の Cu添加では横ばいであった。

(2) 焼結浸炭熱処理材の回転曲げ疲れ強さは，1 mass\%の Cu 添加により高くなったが, 2 mass\%の Cu添加により低下 し $\mathrm{Cu}$ 無添加材より低くなった.

(3) 低 Mo 系プレアロイ銅粉 $(0.45 \mathrm{mass} \% \mathrm{Mo})$ に $1 \mathrm{mass} \%$ の $\mathrm{Cu}$ 添加した焼結浸炭熱処理材は, 従来4 Ni系合金材と同等の 引張強さ, 回転曲げ疲れ強さが得られた。

(4) 2 mass\%の Cu添加では, $\mathrm{Cu}$ 液相の流出孔に起因する最大

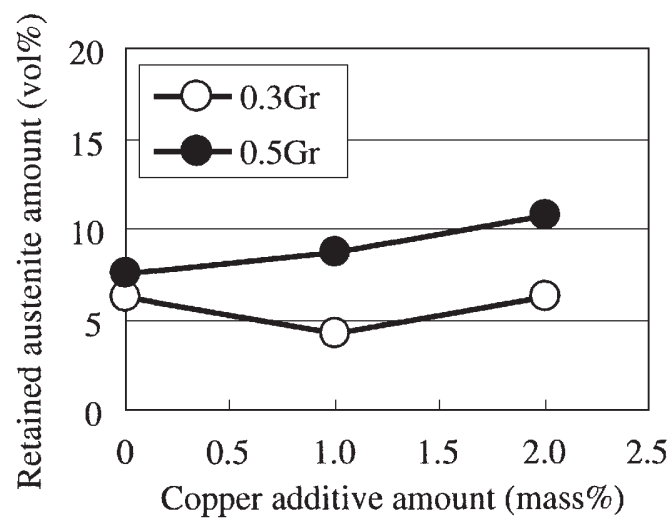

Fig 9 Effects of copper addition on retained austenite amount of the sintered and case-hardened compacts made of the low molybdenum prealloyed steel powder.

(a) $0 \mathrm{Cu}-0.3 \mathrm{Gr}, 3.5 \times 10^{6}$ cycles

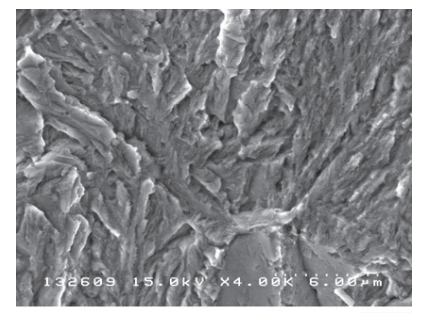

(b) $1 \mathrm{Cu}-0.3 \mathrm{Gr}, 1.7 \times 10^{6}$ cycles

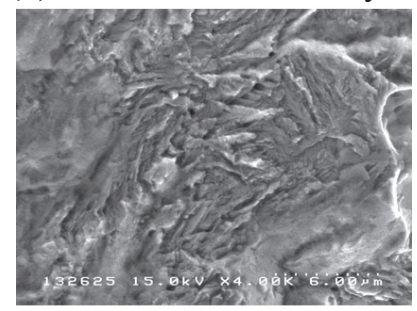

(c) $2 \mathrm{Cu}-0.3 \mathrm{Gr}, 3.4 \times 10^{5}$ cycles

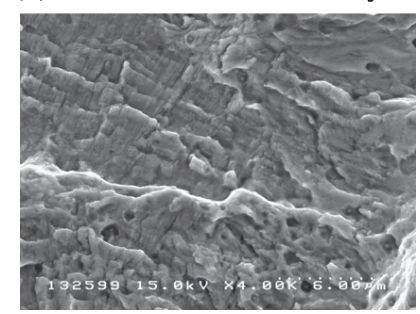

Fig.10 Fatigue fracture surfaces of the sintered and case-hardened compacts made of the low molybdenum prealloyed steel powder with copper addition ( 0.3 mass $\%$ graphite addition).

気孔径の増加に加え, $\mathrm{Cu}$ 添加によるき裂進展速度の増加 も疲労強度を低下させる原因として影響している可能性 が高いと考えられる.

\section{文献}

1) K. Ogura, T. Abe, Y. Makiishi, S. Takajo, T. Minegishi, and E. Hatsugai: "Properties of High Compressibility CompositeType Alloy Steel Powders, "KIP SIGMALOY"", KAWASAKI 
STEEL TECHNICAL REPORT, 18(1988)66-72.

2) S. Unami, Y. Ozaki, and T. Ono: "Properties of Sintered Compacts made of Fe-Mo based Segregation Free Powder", Abstracts of Spring Meeting of Jpn. Soc. Powder Powder Metallurgy, (2008) 215.

3) A. Fujiki and M. Kano: "New PM Valve Seat Insert Materials for High Performance Engines", SAE Paper, 920570, (1992).

4) B. Lindqvist: "A Molybdenum-alloyed PM Steel for surface hardening", Proceedings of World Congress on Powder Metallurgy, 2(1990) 170-177.

5) J.J. Fulmer and R.J. Causton: "Tensile, Impact and Fatigue Performance of a New Water Atomized Low-Alloy PowderAncorsteel 85 HP", Advances in Powder Metallurgy and Particulate Materials, 2(1990)459-486.

6) S. Saritas, R. Causton, W.B. James, and A. Lawley: "Effect of Microstructural Inhomogeneties on the fatigue crack growth response of a prealloyed and two hybrid P/M steels", Advances in Powder Metallurgy and Particulate Materials, MPIF, Part5, (2002)136-148.
7) S. Saritas, R. Causton, W.B. James, and A. Lawley: "RotatingBending Fatigue of Pre-alloyed and Hybrid P/M Steels", International Journal of Powder Metallurgy, 41 (2005)63-70.

8) Y. Ozaki, S. Unami, and T. Ono: "Premixed Iron Powder "JIP Clean Mix HDX" Providing High Green Density without Powder Heating Units", J. Jpn. Soc. Powder Powder Metallurgy, 56(2009)85-87.

9) K. Mashima and H. Mitani: "On the Sintering Mechanism of Fe-Cu-C Ternary Mixed Powder Compacts", J. Japan Inst. Metals, 40(1976)327-333.

10) M. Cohen, Trans ASM, 41(1949)35-94.

11) R.H. Richman and R.W. Landgraf: "Some Effects of Retained Austenite on the Fatigue Resistance of Carburized Steel", Met. Trans. A, 6A(1975)955-964.

12) H.J. French: "Fatigue and the Hardening of Steels", Trans. A. S. S. T., 21(1933) 899-946.

13) H.E. Frankel, J.A. Benett, and W.A. Pennington: "Fatigue Properties of High Strength Steels", Trans. ASM, 52(1960) 257-276. 